\title{
Synodality, Discernment, Catholic Movements
}

\begin{abstract}
One of the basic categories used to describe the nature of the Church is communion with its spiritual, structural, and legal dimensions. On the basis of their baptism, all the faithful should undertake common responsibility and real care for the life and particular areas of the Church. This also includes discernment within the Church. Synods and synodality are a special case which expresses the communal character of the Church.

However, synodality and communal discernment cannot be understood similarly to a parliament where the majority decides. It is about recognising contemporary needs and searching for the place of the Church in the world while preserving the Revelation.

In recognising the ways for the Church, her movements are important as they form Catholics who increasingly identify with the mission of the baptised. Deepening their meaning and determining the degree of their influence on discernment in the Church, both universal and local, remains a challenge.
\end{abstract}

Keywords: synodality, discernment, lay involvement, church structure, church movements and communities

The modern Church is increasingly open to more lay participation in its life and mission. However, it would be wrong to see this movement merely as a result of people's expectations and global trends leading to broader democratisation or to emphasising of one's own autonomy. For the Church, these processes find their source in the Gospel and Jesus' idea of the community of the baptised. Therefore, it is natural for her to seek solutions more adequate to God's plan. This is especially true of the common responsibility of the baptised. Therefore, no wonder there are questions about limits to this participation, opportunities to interact with the clergy and to participate in the exploration and management of the Church. For it is impossible to limit the commitment of believers only to 
active participation in the liturgical life and organisation of various activities. The participation of the lay in the life of the Church means that they are an integral part of the Body of Christ, with a multidimensional shared responsibility.

Considering the reality of the Church and answering the questions, it is necessary to present various types of church movements, communities, and associations of believers, which have become an integral part of her, at different levels of ecclesiastical life: general, diocesan, or parish. And although the tasks of evangelisation and formation are undeniable, it is still necessary to theologically and pastorally deepen the understanding of the movements' place in the Church, especially in the broad understanding of the real common responsibility for specific areas of life of the community of the baptised. Structurally, this comes true in the synodal reality and other forms of discernment in communities.

To solve this problem, it is necessary to first define the concepts, to determine the theological and canonical possibilities of participation of the lay in the Church, and then to indicate the significance of church movements in discerning and deciding. Taking this into account, it is possible to define the challenges for the Church and to see the prospects for further research.

\section{Synodality and discernment in the Church}

Discernment is the work of the entire Church. Only in this way it is possible to fulfill Christ's mission by the clergy and the lay in unity. ${ }^{1}$ Since all of those baptised in the power of Holy Baptism are members of the community, they accept joint responsibility, with the observance of separation of their competences. However, it is not about some parliamentary model, but listening to the Holy Spirit and being able to recognise the true needs of believers. In this process, it is necessary to respect the hierarchical (apostolic) structure, which means that the decision needs to be made by pastors (bishops within the diocese and parish priests in the parish).

${ }^{1}$ At the beginning of 69 th Synod of Bishops of Poznań Archbishop Stanislaw Gądecki drew attention to the fact that "...the entire Church is obliged at all times to seek ways and means to answer to Christ with the faith which the Apostle has shown [...]. If the Synod is to bear the expected fruits [...], then the commitment and prayer of all believers is required...". Synod Archidiecezji Poznańskiej 2004-2008. Tom I. Dokumenty. Eds. Z. Fortuniak et al. Poznań 2008, p. 531. Translation mine - P.S. 


\subsection{Synodality as the way of the Church}

Synodality is an integral constitutional element of the Church and an expression of its communal nature. Pope Francis drew attention to this, saying that "the world [...] demands that the Church strengthen cooperation in all areas of her mission. It is precisely this path of synodality which God expects of the Church of the third millennium" 2 to realise the model of the Church as the home and the school of communion. ${ }^{3}$ So, modernity demands answers to all the new questions and circumstances in which the Church must find herself to be authentic and worthy to fulfill her mission. This is possible only through having a broad view and not being limited only to one solution to a problem. Therefore, as Francis notes, "synodality, as a constitutive element of the Church, offers us the most appropriate interpretive framework for understanding the hierarchical ministry itself. [...] Church and Synod are synonymous in as much as the Church is nothing other than the journeying together of God's flock along the paths of history towards the encounter with Christ the Lord..."4

Synodality is primarily realised by the institution of the Synod of Bishops which was established as "a permanent Council of bishops for the universal Church." ${ }^{5}$ In this way, bishops take responsibility for the universal Church, helping the Pope to discern the matters of Church's life and mission. ${ }^{6}$ Lay participation, however, is limited to the functions of observers or sometimes auditors. However, even then the presence of lay people is important in the search for solutions. For we must remember that the Synod is not only a meeting of its members, but also a time of prayer, conversation, and consultations. Here the role of the lay is irreplaceable. It was voiced during synods dedicated to the New Evangelisa-

${ }^{2}$ Francis: Address of His Holiness Pope Francis [17.10.2015]. http://w2.vatican.va /content/francesco/en/speeches/2015/october/documents/papa-francesco_20151017_50 -anniversario-sinodo.html (accessed: 10.12.2019).

${ }^{3}$ John Paul II: Apostolic Letter Novo millennio ineunte [6.01.2001], n. 43.

${ }^{4}$ Ibidem.

${ }^{5}$ Paul VI: Apostolic Letter Apostolica Sollicitudo. Acta Apostolicae Sedis [rhereafter: AAS] 57 (1965), p. 776; Vatican Council II: Decree on the mission activity of the Church “Ad gentes" [18.11.1965], n. 28.

${ }^{6}$ Cf. Vatican Council II: Decree concerning the Pastoral Office of Bishops in the Church Christus Dominus [28.10.1965] [hereafter: CD], n. 5. "As legitimate successors of the Apostles and members of the episcopal college, bishops should realize that they are bound together and should manifest a concern for all the churches. For by divine institution and the rule of the apostolic office each one together with all the other bishops is responsible for the Church." Ibidem, n. 6, p. 3. 
tion, the family or the young. Therefore, in view of greater lay participation, it is encouraging that the form of the Synod of Bishops is not ultimately defined. This was confirmed by John Paul II who said that this can be made even better and thus collegial pastoral responsibility could be expressed even more fully. ${ }^{7}$

On the other hand, diocesan or provincial synods occupy an important place at the local level, ${ }^{8}$ attended by both priests and laity. The importance of this congregation should be recognised in the light of Second Vatican Council's teachings. It described bishops' office as service dependent on proper discernment possible only through the knowledge of God's People - "In exercising their office of father and pastor, bishops should stand in the midst of their people as those who serve. Let them be good shepherds who know their sheep and whose sheep know them," and for the proper care of believers they "should strive to become duly acquainted with their needs in the social circumstances in which they live." 10 At the same time, they must ensure that believers participate in the affairs of the Church. ${ }^{11}$ During synods, apart from the plenary session and individual commissions, the work of parish and community groups established in accordance with the decision of the diocesan Bishop is also very important.

Archbishop Leonardo Sandri also noted that a synod, "allows to take stock of the work of the Church, to evaluate pastoral ministry, to review the pastoral means of influence and their effectiveness. It is also used to develop and implement new methods of evangelical ministry..."12 This is a form of realisation by the Bishop of his own diocesan function thanks to the support of synod members exchanging views. Although their statements are advisory in nature, they serve to build the unity of the Church as a synod becomes a space for the dialogue of the clergy with the lay. ${ }^{13}$ On the other hand, according to John Paul II, during a synod there is an intertwining of traditions and modernity, which makes it possible to

${ }^{7}$ Giovanni Paolo II: Discorso di Giovanni Paolo II a conclusione della VI Assemblea Generale del Sinodo dei Vescovi. See: http://www.vatican.va/content/john-paul-ii/it /speeches/1983/october/documents/hf_jp-ii_spe_19831029_sinodo-vescovi.html (accessed: 16.09.2019).

${ }^{8}$ Code of Canon Law [15.01.1983] [hereafter: CIC] can. $443 \S 4 ; 463 \S 1$. Cf. S. Tymosz: Recepcja nauczania Jana Pawta II $w$ uchwatach Drugiego Polskiego Synodu Plenarnego. Lublin 2010, pp. 25-31.

${ }^{9}$ CD, n. 16.

${ }^{10}$ Ibidem.

11 Cf. ibidem.

12 Synod Archidiecezji Poznańskiej..., p. 534.

${ }^{13}$ Cf. ibidem, pp. 604-605. 
recognise the correct answers to the needs of believers and to make the ministry of the Church more and more efficient. ${ }^{14}$

\subsection{Other forms of joint responsibility of clergy and laity}

However, discernment is not limited to synods, but should be a permanent form of responsibility where clergy and laity fulfill their calling to build the Church. In the universal Church this can happen through the hearing of individual lay in various central forums such as at the Synod of Bishops, conferences organised by Vatican dicasteries and through the participation of the lay faithful in the realisation of specific tasks. At the national or regional level, "the insights of prudence and experience have been shared and views exchanged" 15 at Episcopal Conferences which occupy a special place in the discernment process. This task is supported by committee advisers, such as presbyters, deacons, the religious, or laity, depending on their backgrounds and on what is needed at the moment. The diocesan level, in turn, includes an advisory council, a priests' council, and a diocesan curia. These bodies support the bishop of the diocese in carrying out his pastoral mission in the local Church. Simultaneously, the correct process of recognising the needs and best plans for dioceses cannot take place without the participation of the laity. Without their voice, it is difficult to make a correct assessment of various areas of Church's life. This discerning together is carried out through the cooperation of clergy and laity, various diocesan groups, formal or less organised, such as meetings of Church movements' leaders or participation of laity in various councils. Therefore, it is not surprising that the Charter of the Pastoral Council of the Diocese of Kalisz includes the following phrase: “[...] the Council performs its tasks by discerning the state of religious and moral life of the faithful in the Diocese; introducing the Bishop into the pastoral needs of believers [...]."16 Therefore, believers should inform the bishop of their views and proposals, and the bishop should listen carefully to the lay voice. That way, the ministry of the bishop along with the real shared responsibility of the faithful is preserved.

${ }^{14}$ Cf. W. Ziemba: "Homilia na otwarcie I Synodu Archidiecezji Warmińskiej.” In: I (XIV) Synod Archidiecezji Warmińskiej (2006-2012). Eds. W. NowaK et al. Olsztyn 2012 [hereafter: Warmia], p. 156.

15 CD, n. 37.

16 Pierwszy Synod Diecezji Kaliskiej (2007-2009). Prawo diecezjalne Kościoła Kaliskiego. Eds. J. BąK, N. Buerger. Kalisz 2009, p. 196. Translation mine. 
Speaking of discernment, it is also worth paying attention to prophetic charisma, manifested not only in charismatic communities, but also generally in the listening of the faithful to inspirations which requires proper theological and pastoral evaluation. The biblical testimony is the missionary service of St. Paul and his companions through the Holy Spirit. The experience of the first Christians is still a challenge for the modern Church where the office of a prophet can no longer be found. Prophecies themselves began to be limited to the preaching of the correct doctrine of faith. Still, this gift of God with all its variants should be properly explored. This is because prophesying is connected with Holy Spirit's charisms and hierarchical service. Thus, through prophecy, the Church can foresee future events but, above all, accept the updates of God's message. It is necessary, however, to stay in line with the ministry of bishops whose authority is also charismatic. Clergy, however, must obey the Holy Spirit which also means listening to the voice of God's people.

\subsection{Basics of synodality and community discernment}

Synodality and community discernment are within the nature of the Church as a community - a synod means "journeying together - laity, pastors, the Bishop of Rome - is an easy concept to put into words, but not so easy to put into practice." ${ }^{17}$ Still, this is a way to preserve the biblical vision of the Church. Therefore, it is now good to highlight the theological foundations of the widely understood synodality.

First, the participation and shared responsibility of the laity stems from their baptism and incorporation into the Church ${ }^{18}$ and from their charismatic gifts. ${ }^{19}$ Therefore, it must be remembered that "Every authen-

${ }^{17}$ Francis: Address of His Holiness Pope Francis [17.10.2015]. http://w2.vatican.va /content/francesco/en/speeches/2015/october/documents/papa-francesco_20151017_50 -anniversario-sinodo.html (accessed: 10.12.2019).

18 "L'ecclesiologia del Popolo di Dio sottolinea infatti la comune dignità e missione di tutti i Battezzati, nell'esercizio della multiforme e ordinata ricchezza dei loro carismi, delle loro vocazioni, dei loro ministeri. Il concetto di comunione esprime in questo contesto la sostanza profonda del mistero e della missione della Chiesa, che ha nella sinassi eucaristica la sua fonte e il suo culmine.” InTERnational Theological Commission, La sinodalità nella vita e nella missione della Chiesa. http://www.vatican.va/roman_curia/congregations/cfaith /cti_documents/rc_cti_20180302_sinodalita_it.html (accessed: 21.09.2019).

${ }^{19}$ The faithful have the right and obligation to make use of charisms. Vatican CouncIL II: Decree on the Apostolate of the Laity Apostolicam actuositatem [hereafter: AA], n. 3. Holy Spirit "calls the faithful to various offices and states for the greater good 
tic charism implies a certain element of genuine originality and of special initiative for the spiritual life of the Church." ${ }^{20}$ Still, the Eucharist with its vertical and horizontal aspects is the centre of this communion. ${ }^{21}$

Next, the Church as a whole also enjoys the privilege of infallibility. The faithful in unity with bishops and the Pope participate in the discernment of truth thanks to the Holy Spirit. This has been highlighted by the Second Vatican Council in its teachings about the supernatural sense of faith: "[...] the entire body of the faithful, anointed as they are by the Holy One, cannot err in matters of belief. They manifest this special property by means of the whole peoples' supernatural discernment in matters of faith when from the Bishops down to the last of the lay faithful they show universal agreement in matters of faith and morals." 22

Then, diocesan synods prove that Church in its nature is a communion and is a "renewal of the charism of being called." 23 Thus, clearly it has a spiritual character, aimed at growing in the love of God. So, it cannot be seen as anything close to a parliament in the Church. It needs to be accepted in accordance with the Acts of the Apostles - as a meeting of brothers in faith. Thus, the prayer aspect is the most important. ${ }^{24}$

of the Church. It is evident that no obstacles should be placed in the way of such divine action; on the contrary, each one should be enabled to respond to his calling with the greatest freedom [...]." SACRed Congregation for Religious and for Secular Institutes, SACRED Congregation For Bishops: Mutuae relationes. Directives for the mutual relations between bishops and religious in the Church [14.05.1978] [hereafter: MR], n. 39.

${ }^{20}$ MR, n. 12.

${ }^{21}$ Cf. Congregation for the Doctrine of the Faith: Letter to the Bishops of the Catholic Church on some aspects of the Church understood as communion [28.05.1992] [hereafter: $\mathrm{CN}]$, n. 5.

${ }^{22}$ Vatican Council II: Dogmatic Constitution on the Church Lumen gentium [21.11.1964] [hereafter: LG], n. 12.

${ }^{23}$ W. Zıемba: "Homilia podczas Godziny Przedpołudniowej na rozpoczęcie II Sesji Plenarnej I Synodu Archidiecezji Warmińskiej." In: Warmia, p. 159.

${ }^{24}$ The experience of the conference of bishops in Aparecida in 2008 is a testimony for the wide cooperation of bishops and faithful. It is described by Pope Francis as a moving participation of the Holy Spirit in the Church — work done without an introductory document, faith-wise discernment and the companionship of the faithful through prayer in the sanctuary. Cf. G. RYś: "Rozmawiając z Franciszkiem o Dokumencie z Aparecidy." In: Aparecida. V Ogólna Konferencja Episkopatów Ameryki Łacińskiej i Karaibów. Dokument końcowy. Trans. K. Zabawa, K. ŁuкAszczyк. Gubin 2014, pp. 8-9. 


\subsection{Limits of synodality and joint responsibility in the Catholic understanding}

Synodality is a great gift for the Church as it highlights its communal character. It is also means of ownership for her life and mission by the spiritual and the lay. However, Catholics cannot understand it as means of democracy or choosing what the majority prefers. Specific border points are to be taken into account. These include doctrinal purity, Church's unity and the good of the faithful. Only then it is possible to develop the Church sustainably.

The first border point is doctrinal purity. Nobody except the Ecclesiastical Magisterium has the right to decide on dogmatic matters. ${ }^{25}$ This does not forbid theological research and analysis of the faith by God's people. ${ }^{26}$ Dogmatic fidelity is also manifested in maintaining the correct structure of the Church which is hierarchical and sacramental. ${ }^{27}$ Therefore, synodality and ecclesiastical discernment cannot lead to modifying of the identity of the spiritual or the lay. It is necessary to avoid belittling of mission of bishops and presbyters' mission as they are responsible for pastoral service. On the other hand, it would also be wrong to reduce the voice of believers. A model of cooperation and shared responsibility is thus needed, with respect for the competencies stemming from one's own place in the Church. Therefore, the sanctification of clergy or "clericarisation" of the laity is contrary to the nature of the community of the baptised.

The second criterion of the correctness of the discernment process is the concern for the unity of the Church. She is of course not a monolith, but at the same time she is not a coexistence of different perspectives

25 "But the task of authentically interpreting the word of God, whether written or handed on, has been entrusted exclusively to the living teaching office of the Church, whose authority is exercised in the name of Jesus Christ." Vatican Council II: Dogmatic Constitution on Divine Revelation Dei Verbum [18.11.1965], n. 10.

${ }^{26}$ Growth in the understanding of faith is accomplished through contemplation and reflection of believers, the work of theologians, the understanding of spiritual affairs, or the Ministry of the preaching by the clergy. Cf. Catechism of Catholic Church [11.10.1992], n. 94.

27 " [...] the hierarchical gifts proper to the sacrament of Orders, in its diverse grades, are given so that the Church as communion may never fail to make to each member of the faithful an objective offer of grace in the sacraments, and so She may offer both a normative proclamation of the Gospel and pastoral care." CONGREgation FOR THE Doctrine of The Faith: Letter Iuvenescit Ecclesia to the Bishops of the Catholic Church Regarding the Relationship Between Hierarchical and Charismatic Gifts in the Life and the Mission of the Church [15.05.2016] [hereafter: IE], n. 14. 
on doctrinal teaching. An example of the importance of the situation is the synodal process started in Germany. And although a plenary synod as described by the canon law is a space for meeting and taking ownership for the Church in a given country, the German proposition goes way further. It suggests that matters out of reach for local Churches or episcopal conferences, such as understanding of power, sexual morality, form of priesthood (celibacy) and participation of women in Church services and offices (including ordination) should also be in scope of discussions. Therefore, in a letter addressed to Cardinal Reinhard Marx, Pope Francis noted that the synodal way is to listen to the Holy Spirit in unity with the universal Church which has its place in local discernment. In addition, the entire road to the restoration of the Church cannot take place primarily through structural, organisational and administrative reforms, but through the return to evangelization. ${ }^{28}$ At the same time, it is necessary to harmonise the universal and the particular dimensions of the Church in order to preserve the identity of the Church. ${ }^{29}$

The third important border point is to focus on the good of the entire Church and individuals as well, while preserving the Revelation. Bearing in mind the abundance of people's talents and their desire to accept common responsibility, it is worth remembering that "the charismatic gifts given to individuals actually belong to the Church herself and are ordered towards a more intense ecclesial life." ${ }^{30}$ Spiritual affinity is also born through cooperation and participation, ${ }^{31}$ which allows us to walk the same road and search for solutions not through a decision of the majority, but through the search for the best answer to God's calling.

${ }^{28}$ As noted by the Holy See, the Synod of German bishops in the proposed composition will be invalid ecclesiologically as it contains the proposition of partnership between bishops and the Central Committee of German Catholics (a group proclaiming views that are contrary to Church's teaching, especially when it comes to sexual ethics and ordination of women). See "Watykan przestrzega biskupów niemieckich przed 'drogą synodalną,." See: http://www.gosc.pl/doc/5850492.Watykan-przestrzega-biskupow-nie mieckich-przed-droga-synodalna (accessed: 13.09.2019).

${ }^{29}$ Cf. CN, n. 7-10.15-16.

${ }^{30}$ IE, n. 13.

${ }^{31}$ John Paul II: Apostolic Exhortation Christifideles laici [30.12.1988] [hereafter: ChL], n. 24. 


\section{Participation of lay people in the process of discernment under the current legislation}

Active and subjective presence of the laity in the Church, especially those forming various groups, communities, associations and movements, is widely accepted nowadays. This includes not only practical participation, but also co-exploration, co-execution of Church's missions and the co-formation of the life of the community of the baptised. A new view, started with the teachings of the Second Vatican Council found its actualisation in pastoral practice and canon law. In this context it is worth highlighting the current theological and legal state of lay participation.

\subsection{Rights and duties of laity}

The Second Vatican Council emphasised the importance of the lay and also pointed to new accents and competences. ${ }^{32}$ The biblical basis of this is the fact of incorporation into Christ through baptism, which made the living bedrocks of the Church and members of one Body from the faithful children of God. ${ }^{33}$ This is the foundation of the ecclesiology of communion that reflects the truth about the unification of believers through the Word of God and the sacraments, and about the organic unity of the baptised. Thus, the Church cannot be seen pyramidically but communally. The Church is not a monolith, but a unity expressed in diversity and complementarity. That way, the lay cannot be seen merely as objects but as subjects, since they participate in the threefold mission of Christ: priestly, prophetic, and kingly. This is appropriately accomplished through prayer and sacramental life, witnessing and sharing the Gospel, and giving oneself through the acts of love. This mission has its source and strength in the Christian initiation. It also relates to the equal dignity of all the baptised, regardless of vocation, ${ }^{34}$ although the lay nature is to be retained. ${ }^{35}$

${ }^{32}$ It was Pius XII who already stated that the laity not only belong to the Church, but in fact are its part in unity with the Pope and the bishops. Cf. AAS 38 (1946), p. 149.

${ }^{33}$ Cf. ChL, n. 9-13.

${ }^{34}$ ChL, n. 15.

${ }^{35}$ Cf. LG, n. 31. It is still necessary to deepen the formation of the vocation of the lay. Cf. La Chiesa italiana e le prospettive del Paese Documento del Consiglio Permanente, 22-23, http://www.chiesacattolica.it/wp-content/uploads/sites/31/2017/02/La_Chiesa_ italiana_e_le_prospettive_del_Paese.pdf (accessed: 14.09.2019). 
However, in some circumstances the lay may be entrusted with certain functions in lieu of the spiritual, for instance, with the ministry of the word, leading of some liturgical prayers, baptising of others or distributing the Blessed Sacrament. Still, even then they do not lose their secular personality. ${ }^{36}$ Regardless of the area of lay participation, it should be emphasised that their ministry cannot be limited to participation in the affairs of the world, but it is necessary to appreciate their mission in life and mission of the Church. ${ }^{37}$ The Second Vatican Council clearly stated that the Holy Spirit is "making the laity ever more conscious of their own responsibility and encouraging them to serve Christ and the Church in all circumstances." 38

The Code of Canon Law precisely defines the rights, duties and responsibilities of lay believers. The basis for this is the baptism through which the faithful "have been incorporated in Christ [...], have been constituted as the people of God and [...] are called to exercise the mission which God has entrusted to the Church to fulfill in the world." 39 This is the source of true equality regarding dignity and action by which they all cooperate in the building up of the Church, ${ }^{40}$ which does not reduce the diversity of actions, particularly those associated with clergy's vows. However, they are called to assume responsibilities on both global and local ${ }^{41}$ levels, bearing in mind the common good of the community of the baptized. ${ }^{42}$

\subsection{Levels of the responsibility of the lay}

The responsibility of the lay take is there on several levels: of the Christian life, of cooperation, and of commitment. Surely the first is living according to the Gospel which builds the Church and shows her holi-

${ }^{36}$ ChL, n. 23.

37 Cf. "Evangelizzazione e ministeri. Documento pastorale dell'Episcopato italiano." In: Notiziario della Conferenza Episcopale Italiana a cura della Segreteria Generale. Roma 1977, no. 7, p. 133.

${ }^{38} \mathrm{AA}, \mathrm{n} .1$. In this context, Benedict XVI stated that "the lay cannot be seen only as associates for the clergy, but also as people actually co-responsible for the existence and actions of the Church." Kim jest świecki?. See: http://www.papiez.wiara.pl/doc/1272559 .kim-jest-swiecki (accessed: 15.09.2019).

${ }^{39}$ CIC, can. $204 \S 1$.

40 CIC, can. 208.

${ }^{41}$ It is the duty of faithful to preserve unity with the Church. Cf. CIC, can. 209.

${ }^{42}$ Cf. CIC, can. 222-223. 
ness. ${ }^{43}$ However, one cannot limit the responsibility of the lay only to the spiritual and moral aspects. They also have to take part in preaching the Word of God. ${ }^{44}$ It is not surprising, therefore, that "lay persons who are found suitable are qualified to be admitted by the sacred pastors to those ecclesiastical offices and functions which they are able to exercise according to the precepts of the law." 45 When analysing the state of the Church, it is easy to see that the division of responsibilities or offices occurs especially in regions that struggle with the lack of an adequate number of presbyters. Meanwhile, the participation of lay people cannot be understood only as a sociologically induced reality.

In addition, an important aspect is the relationship between obedience and the expectation of satisfaction of needs. On the one hand, the faithful are obliged to obey pastors as teachers of faith and governors of the Church, but on the other - pastors cannot ignore the needs of the faithful. ${ }^{46}$ Establishment of new associations and following their goals are a very important dimension of execution of this goal. Still, it is necessary to respect the care for the catholic nature of works undertaken. ${ }^{47}$ This applies not only to dioceses, but first of all to parishes where the parish priest has to support believers in pursuit of their mission, taking care of the ecclesial nature of their work. ${ }^{48}$

The responsibility of the lay is also expressed in advising on various issues and participating in relevant councils. Of course, appropriate powers are necessary to undertake these tasks. ${ }^{49}$ This is done by discerning spiritual needs. On the one hand, believers have the right to grow and receive appropriate assistance from the hierarchical Church. ${ }^{50}$ On the other, due to their involvement in the affairs of the world and

43 "All the Christian faithful must direct their efforts to lead a holy life and to promote the growth of the Church and its continual sanctification, according to their own condition" (CIC, can. 210).

${ }^{44}$ Cf. CIC, can. 211. "In the case of coming generations, the lay faithful must offer the very valuable contribution, more necessary than ever, of a systematic work in catechesis" (ChL, n. 34).

${ }^{45}$ CIC, can. $228 \S 1$.

46 "The Christian faithful are free to make known to the pastors of the Church their needs, especially spiritual ones, and their desires." CIC, can. 212 § $1-2$.

${ }^{47}$ CIC, can. 215-216. This is especially important when it comes to theological studies which are also undertaken by lay people. For it is necessary to keep the boundaries set by the Magisterium. Cf. CIC, can. 218.

${ }^{48}$ CIC, can. $529 \S 2$.

49 “According to each one's own condition, they are also bound by a particular duty to imbue and perfect the order of temporal affairs with the spirit of the gospel and thus to give witness to Christ, especially in carrying out these same affairs and in exercising secular functions." CIC, can. $228 \S 2$.

${ }^{50}$ Cf. CIC, can. 213. 
knowledge of its state, they should participate in the preaching of the Word of God. Therefore, a cooperation between clergy and laity is necessary in this regard. ${ }^{51}$ For every baptised person, regardless of their vocation, is called for evangelisation. ${ }^{52}$ In the case of the lay, it is primarily by means of giving testimony, but also through active participation in preaching the Christian truth, ${ }^{53}$ without abandoning their position in the world. ${ }^{54}$ At the same time, they are called to recognise the needs of God's people and to ensure that they are appropriately catered for. ${ }^{55}$ This is particularly evident at the parish level, where believers can care for the Church unity and evangelise non-believers or those who neglect their Christian life. ${ }^{56}$

\subsection{Specific tasks and possibilities in shared responsibility}

The participation of lay people in the Church also involves specific tasks, including real participation in the discernment of various issues. The Code of Canon Law draws attention to the importance of the economic council and the pastoral council which should not only consist of clergymen, but also of competent lay. Thus, each diocese should have an economic council consisting of at least three faithful skilled in economics with proper knowledge and ethics. ${ }^{57}$ Similar councils should also be present in parishes in order to support the parish priest in the management of mate-

51 "According to the knowledge, competence, and prestige which they possess, they have the right and even at times the duty to manifest to the sacred pastors their opinion on matters which pertain to the good of the Church...". CIC, can. $212 \S 3$. The call to take up evangelisation is based on the fact that the lay live in "all of the secular professions and occupations. They live in the ordinary circumstances of family and social life, from which the very web of their existence is woven." LG, n. 31.

52 "[...] lay persons [...] are bound by the general obligation and possess the right as individuals, or joined in associations, to work so that the divine message of salvation is made known and accepted by all persons everywhere in the world [...]." CIC, can. 225 $\S 1$.

53 “"...] they can also be called upon to cooperate with the bishop and presbyters in the exercise of the ministry of the word" (CIC, can. 759). "Lay persons can be permitted to preach in a church or oratory, if necessity requires it in certain circumstances or it seems advantageous in particular cases, according to the prescripts of the conference of bishops and without prejudice to can. 767 §1." CIC, can. 766.

${ }^{54}$ ChL, n. 15.

${ }_{55}$ Cf. AA, n. 10.

56 ChL, n. 27.

57 Cf. CIC, can. 492. 
rial goods in the parish. ${ }^{58}$ It is also worth noting that the legislator recommends that each legal entity should have its own economic Council. ${ }^{59}$

The participation of lay people in the pastoral activities of the Church is also important. In dioceses it is realised through participation in the diocesan pastoral council as recommended by the Second Vatican Council. ${ }^{60}$ The council contemplates and assists the bishop in the discernment of issues relating to the execution of the mission and life of the Church. Such a council consists of Catholics in full communion with the Church who are virtuous and reasonable. The council should well represent the People of God and specific areas of participation in the apostolate. ${ }^{61}$ Although presence of such a council is not mandatory, its very existence reflects the nature of the Church as a community of the baptised. This is because it expands the room for necessary consultations, and more often than not for making decisions, ${ }^{62}$ which makes discernment more accurate. Similar pastoral councils may or should also be founded in parishes, depending on the decision of bishops. This supports parish priests in the execution of pastoral tasks. Council members, however, act as advisors. The scope and competences of the councils are governed by norms established by the diocesan bishops. ${ }^{63}$ Still, it is worth remembering that it is not only about the representation of lay people, but also about the faithful being conscious of the meaning of Church as a community and their real and active participation. So, it is about being a true subject of life and mission of the Church. Thus, the real challenge is quality and not quantity or a "sense of Church." Only then can one discern, support the decision making and accept resolutions being made. It is the realisation of the communal nature of the Church. Eugeniusz Weron notes that "with

${ }^{58}$ CIC, can. 537.

59 CIC, can. 1280.

60 "The duty of this commission will be to investigate and weigh pastoral undertakings and to formulate practical conclusions regarding them." CD, n. 27.

${ }^{61}$ CIC, can. 529.

62 "The participation of the lay faithful in these Councils can enrich resources in consultation and the principle of collaboration - and in certain instances of decisionmaking - if applied in a broad and determined manner." ChL, n. 25. "The competence of the Council includes the analysis of pastoral problems, formulation of practical conclusions and presentation of draft decisions to the Bishop of Płock." Gdzie jest Bóg, tam jest przyszłość. XLIII Synod Diecezji Płockiej. Prawo partykularne i program odnowy pastoralnej Kościoła Płockiego. Ed. H. Seweryniak. Płock 2015 [hereafter: Płock], p. 358. Translation mine. "The task of the Pastoral Council is to prepare, study, contemplate, and exchange experiences or creative projects relating to pastoral care and to inspire useful pastoral initiatives in the diocese and in parishes." Pierwszy Synod Diecezji Opolskiej (2002-2005). Statuty i aneksy. Parafia u progu nowego tysiaclecia. Eds. H. SobeczKo et al. Opole 2005 [hereafter: Opole], p. 182. Translation mine.

${ }^{63}$ CIC, can. 536. Cf. IV Synod Archidiecezji Warszawskiej. Warszawa 2003, p. 121. 
this new philosophy comes also [...] the principle of joint responsibility and participation of the lay in all aspects of life and work of members of the Church." 64

In addition to the foregoing, other groups that support the process of discernment may come into existence depending on what is needed in a given moment. An example is the diocese of Płock where a Youth Pastoral Council was established to advise the Bishop of the diocese in getting to know the needs and forms of action indispensable for working with the youth. ${ }^{65}$ Another important means is also so-called Youth Synods where the young are invited to participate in co-discernment within the Church. ${ }^{66}$ Another example, this time in the universal Church, is the International Service of Communion Charis created by Pope Francis that assists and discerns the charismatic reality among Catholics, with a clear focus on spiritual sharing with all Catholics. ${ }^{67}$

\section{Catholic movements and discernment}

Church movements with various forms and structures have an important place in the life of the modern Church. Although the phenomenon is not new (history knows various fraternities and third orders), nowadays a strong presence of communities, movements and associations can be seen. Those can be created by the lay or by the lay and the clergy together. At the same time, these associations are taking on more and more tasks. They have therefore become an important element of the structure of the Church at every level. This is the real Kairos of God for the Church. ${ }^{68}$ Thus, "Church movements and associations are not a mere addition or an ornament in her life. They are at the very center of her life and they make that very center of her life." ${ }^{69}$

${ }^{64}$ E. Weron: Powołanie $i$ posłannictwo ludzi świeckich $w$ świetle dokumentów kościelnych. Poznań 1989, p. 276. Translation mine.

${ }^{65}$ Płock, pp. 55-56.

${ }^{66}$ Cf. Synod Młodych Diecezji Warszawsko-Praskiej. See: www.florianska3.pl/synod (accessed: 16.09. 2019).

${ }^{67}$ Cf. Catholic Charismatic Renewal International Service (Charis). Statutes. See: http://www.drive.google.com/file/d/19A1XQekEIo-7FHBnlMcSSAYbpb2aTZlF/view (accessed: 16.09.2019).

${ }^{68}$ E. Weron: Ruchy odnowy we współczesnym Kościele. Poznań 1993, p. 15.

${ }^{69}$ S. Rүєко: Misja Ruchów i Stowarzyszeń na nowe tysiąclecie. See: http://www.orrk.pl /ruchy-katolickie-w-kociele-i-spoeczestwie/134-misja-ruchow-i-stowarzysze-na-nowe-tysic lecie (accessed: 18.09.2019). 


\subsection{Nature of the movements}

The Synod of the Diocese of Opole pointed out the importance of Church movements: "[...] a special place for the laity to participate can be in religious movements and associations which should be supported and surrounded with pastoral care." 70 Forming associations by the faithful is their right that stems from their incorporation in the Church. Movements within the Church are also the natural consequence of their experience of communion. However, not every group of the faithful can be called a Church movement. For them to use the adjective Catholic, a consent of the competent Church authority is required. ${ }^{71}$ In turn, for a community or a group to be considered a Church movement, it must meet the following criteria: putting the call to holiness first, responsibility in professing the Catholic faith, lasting and authentic communion with the Church (including hierarchy), congruency with the apostolic purpose of the Church, participation in the actualisation of the works of evangelisation and sanctification and participation in people's affairs in accordance with the social doctrine of the Church. ${ }^{72}$ These criteria lead to the spiritual growth of the faithful and to deepening of their spiritual identity. ${ }^{73}$ That is why they have a voice during synods and during every day and pastoral discernment. So, it is needed that "mature ecclesial communities, in which the faith might radiate and fulfill the basic meaning of adherence to the person of Christ and his Gospel"74 are formed.

As a result of accepting the existence of Church movements, movements and associations' councils may come to life in a diocese. They aim at coordinating pastoral action, giving a testimony of unity, mutual support, and joint concern for the revival of the Church in terms of evange-

${ }^{70}$ Opole, p. 112.

71 "No association is to assume the name Catholic without the consent of competent ecclesiastical authority [...]." (CIC, can. 300).

${ }^{72}$ ChL, n. 30.

73 "Such as: the renewed appreciation for prayer, contemplation, liturgical and sacramental life, the reawakening of vocations to Christian marriage, the ministerial priesthood and the consecrated life; a readiness to participate in programmes and Church activities at the local, national and international levels; a commitment to catechesis and a capacity for teaching and forming Christians; a desire to be present as Christians in various settings of social life and the creation and awakening of charitable, cultural and spiritual works; the spirit of detachment and evangelical poverty leading to a greater generosity in charity towards all; conversion to the Christian life or the return to Church communion of those baptized members who have fallen away from the faith." ChL, n. 30 .

${ }^{74}$ ChL, n. 34. 
lisation, personal development, spirituality and pastorate. ${ }^{75}$ Also, the very presence of representatives of movements and communities in the bodies of a diocese contributes to the right discernment of the direction of life of the diocese. ${ }^{76}$

\subsection{Movements' contribution to the life of the Church}

The importance of Church movements in the process of discernment can be recognised by thinking of their enormous contribution to the life of the communities of the baptised. The communal character of the Church is realised so clearly with new communities being created all the time. This comes, first of all, from the need to experience a real community, personal relationships, and living the faith in the unity of a community in practice and not just in some sociological theory. An experience of belonging to the Church in this way simultaneously evokes a willingness to accept responsibility, to share one's observations and experiences verified by those responsible and by other members of a community. This is reinforced by the multidimensional formation undertaken by many movements and communities. That is how Catholics understand the Church more and more. That is also how one of the basic criteria of spirituality can be met - sentire cum Ecclesia. This does not mean a denial of personal pastoral preferences, but a mutual exchange of gifts between an individual or a particular community and the Church understood as a whole. Then what is partial and specific to a group becomes the heritage of all. ${ }^{77}$ Therefore, movements should not be necessarily bound by "juridi-

${ }^{75}$ Cf. Płock, pp. 363-364.

76 The Synod of Warmia decided about the Diocesan Pastoral Council that "members of the Council are to voice their own and their peers' opinions during meetings." Warmia, p. 384.

77 "Being members of the Church takes nothing away from the fact that each Christian as an individual is unique and irrepealable. On the contrary, this belonging guarantees and fosters the profound sense of that uniqueness and irrepealability, in so far as these very qualities are the source of variety and richness for the whole Church. Therefore, God calls the individual in Jesus Christ, each one personally by name. In this sense, the Lord's words You go into my vineyard too, directed to the Church as a whole, come specially addressed to each member individually. Because of each member's unique and irrepealable character, that is, one's identity and actions as a person, each individual is placed at the service of the growth of the ecclesial community while, at the same time, singularly receiving and sharing in the common richness of all the Church [...]." ChL, n. 28. 
cal straitjackets that deaden the novelty which is born from the specific experience." On the other hand, it is necessary to protect the Church spirit and, thus, the unity of the Church. ${ }^{78}$ Then, the novelty brought by movements affects the Magisterium and the Church and the hierarchy has an impact on the reality of particular communities. ${ }^{79}$

The Church movements make members feel that they belong to local communitiesand to the Church as a whole. However, the feeling itself is not enough. Through a practical formation of faith, members of movements and communities increasingly discoverthe universality of the Church and achieve the supernatural sense of faith. Professionof correct faith and sincere love for the Church protects believers from the tendenciesof understanding joint responsibility as a parliamentary majority. The ecclesiastical discernment is not a question of the majority's decision, but of the truth congruous withthe will of God.

The existence of various kinds of movements and communities is therefore incredibly life-giving for the entire Church. Through their own ways, they bring renewing accents to the Church and emphasise certain aspects of piety or of execution of the Church's mission(e.g. prayer of praise in charismatic groups, service to the needy by the Sant'Egidio Community, missionary groups focused on discernment for missions ${ }^{80}$ Sometimes the activity of a movement affects not only the local Church, but also the general Church. Movements and communities make it possible to understand the needs of the Church and the world, which is an important elementof Christian vocation. ${ }^{81}$ Properly formed lay can simultaneously recognise people's different expectations, limitations, difficulties and hopes, which becomes necessary to executethe mission of the New Evangelisation.

\section{Challenges of the modern Church}

Lives of the faithful are touched by trends in the modern world, especially by the emphasis of one's own freedoms, autonomy, and the law being decided by the majority. It does not remain without influence on

${ }^{78}$ IE, n. 23.

${ }^{79}$ Cf. IE, n. 2-3.

80 "The activity of the lay faithful, who are always present in these surroundings, is revealed in these days as increasingly necessary and valuable." ChL, n. 35 .

81 "In this work of contributing to the human family, for which the entire Church is responsible, a particular place falls to the lay faithful [...]." ChL, n. 36. 
their understanding of the Church. On the other hand,the very understanding of the Church as a communion allows for a bolder look towards a greater activity of the lay. Therefore, the Church faces specific problems that require specific answers. First of all, we can point to the greater commitment of lay people in the discernment and management in the Church, a deeper appreciation of the importance of Church movements and the integration of the particular with the commonplace.

\subsection{A real appreciation of the place of movements in the Church}

Undoubtedly, the cooperation and common discernment by the clergy and the lay will bring more stress arising from the differences in vocations, lifestyles, and objectives. ${ }^{82}$ Therefore, there must be a mutual understanding and respect for diversity in the Church.The gift of mutual trust remains the challenge here, along with mutual completingof individual (state and personal) charisms or the recognition of the complementarityof vocation. The help in achieving this goal is, first of all, concern for the space of faith. Thus, it would be a mistake to perceive movements and specific bodies with the participation of laity (synods, councils) as kinds of peculiar parliaments.

A focused, not only functional, approach is very important. It is about gathering people around a common goal and about creating a community of people who identifywith the idea, execute it and take responsibility for it. ${ }^{83}$

Correct understanding of the place of movements and communities in the Church, both in the work and in the recognition of signs of times, pastoral needs and directionfor the Church, also remains a problem.

${ }^{82}$ This is not just about modernity. As early as February 20, 1931, Cardinal Jean Verdier, Archbishop of Paris, pointed out some predictable difficulties: "When tomorrow the Catholic action takes its place next to the hierarchy, you will become (already and only) kings in constitutional monarchies. You have to accept the comments that parliaments voice. [...] The spirit of cooperation will be riddled with many tricks [...]." P.J. CORDEs: "Rola ruchów i stowarzyszeń katolickich w Kościele i w nowoczesnym społeczeństwie." In: Chrystus-Człowiek-Społeczności. Wiosna ruchów. Materiały z I Kongresu Ruchów Katolickich. Eds. K. Bolewska, B. JaniкowsкA. Warszawa 1994, p. 41. Translation mine.

${ }^{83}$ Lack of focused approach leads to the individualisation of faith and creation of mentality of service-providing in the fields of religiosity, catechism, and of other activities. 
Unfortunately, it happens that some treat the layas "resources in priests' work, their longa manus - an extension of clergy's arm, representatives to be sent where things get tough, clergy in reserve." ${ }^{84}$ However, it is important that movements and communities' voice grows louder and that it is taken into account in local Church's discernment, especially if it comes to pastoral affairs. ${ }^{85}$

\subsection{Tension between hierarchy and charisms}

The Church is constituted by hierarchical and charismatic endowment. These gifts should be accepted with grace and practiced responsibly. ${ }^{86}$ However, one cannot forget about the specific task of bishops and presbyters who, acting in persona Christi Capitis, take the holy power associated with their ordinations. Therefore, the judgment about authenticity of charisms and their proper use belongs to the hierarchy of the Church, which makes it possible to act for the benefit of the whole community of the baptised. ${ }^{87}$ Therefore, it is impossible to oppose the sacramental (hierarchical) structure to the charismatic and prophetic dimension. The whole history of the Church confirms the coexistence of orders. Starting with the first eremic movements and then born in various forms of monastic life, a charismatic call to the discernment between the needs of the Church and making substantial influences into her life is born. This, however, did not happen outside of the Church hierarchy, but in unity with bishops, especially with the Pope, who were the pillars of the new forms of Christian life that influenced local Churches. As examples we may quote: the spread of Benedictine and Irish-Scottish monasticisms, missions of Cyril and Methodius, medieval reform of monasticism or the spring of mendicant orders that all significantly influenced contemporary Church. And although there were quite a lot of heterodox movements (e.g. Albigenses, Cathars, reform movements), the final balance of origins

${ }^{84}$ P.G. Liverani: Dobre życie Ewangelia. W poszukiwaniu zaginionego powołania. Trans. K. WozniaK. Kraków 2012, p. 87.

85 "It is about making the voice of the lay clearly heard in the Church, and making modern parishes become real communities of communities." Płock, p. 54.

${ }^{86}$ LG, n. 4. Cf. AA, n. 3. "Whether they [charisms] be exceptional and great or simple and ordinary, the charisms are graces of the Holy Spirit that have, directly or indirectly, a usefulness for the ecclesial community, [...] building up of the Church, to the well-being of humanity and to the needs of the world." ChL, n. 24.

${ }^{87}$ LG, n. 12.30. 
and importance of the movements brings a positive assessment of their contribution to the renewal of the Church. This is particularly evident in new post-conciliar movements and communities.

\subsection{Active participation of competent laypeople}

Constantly breaking the paradigm of ruling (hierarchy) and being ruled (the faithful) is a challenge for the contemporary Church. Constant deepening of the meaning of baptismal priesthood of the faithful and of the Holy Spirit's action, that is a source of unity and of complementarity of gifts and services in the Church, has to lead to greater awareness of communion. Therefore, it is necessary that the baptised act together. There can therefore be no question of any division in the Church as it is a single saving work and a single Church. ${ }^{88}$ Yet, this commitment of believers cannot in any way diminish the role of bishops or presbyters acting on their behalf.

However, the role of the laity does not seem to be sufficiently emphasised at present. Although there is no fundamental problem with gathering of people in communities, the real participation of the laity in the work, including management, of various entities in the Church is insignificant. A departure from the model of the Church that teaches and listens towards the idea of the Church as co-participation requires the clergy to share more tasks with the faithful able to perform such services. Thus, the suggestion of the First Synod of the Archdiocese of Warmia that recommends pastors "to entrust the lay faithful with tasks important for the Church, to assist and counsel in initiatives undertaken but with the respect for their freedom and autonomy [...]" is very bold..$^{89}$

At the same time, the Church faces the challenge of active participation of the laity in synodal processes. The final document of the Synod of Bishops on Young People includes an important call for the involvement of non-bishops in community discernment. It also suggests that synods should be characterised by fraternal listening and intergenerational dialogue. ${ }^{90}$ According to the current legislation, lay people can be auditors.

${ }^{88}$ This division would be harmful to the Church. Cf. John Paul II: Crescita comune nell'unità e nella collaborazione reciproca. In: Insegnamenti di Giovanni Paolo II, X, 1, 1987. Vaticano 1988, p. 478.

89 Warmia, p. 95.

${ }^{90}$ XV General Assembly of The Synod of Bishops: Final Document of the Synod of Bishops on Young People, Faith and Vocational Discernment, n. 120. http://www.synod 
Thus, the question of greater involvement of believers in synodal issues remains open as it requires adequate canonical regulation.

Appreciating the role of women in the Church is an equally important issue. ${ }^{91}$ Therefore, it is necessary to continue discussing "the case for the participation of women in the pastoral councils of dioceses and parishes, as well as in diocesan synods and in particular synods. [...] Without discrimination women should be participants in the life of the Church, and also in consultation and the process of coming to decisions." 92 This process comes along in the Catholic Church. An example is the appointment of Linda Ghisoni, Micheline Tenace and Laetitia Calmeyn as the counsellors of the Congregation for the Doctrine of the Faith by Pope Francis ${ }^{93}$ or his appointment of Claudia Ciocca as the Prefect of the Secretariat for the Economy of the Holy See. ${ }^{94}$

\subsection{Common good of the faithful}

Another challenge is the real desire not only to achieve a movement's or a community's own goals but integration with the good of the Church as a whole. So, the right education is needed so that there is an appropriate ecclesiastical vision that includes observance of particular values and the common good of people of God. Under this assumption, it is only possible that the movements have a genuine good influence on the Church and that they co-participate in pastoral discernment. To do this, it is necessary to set right priorities: spiritual renewal, expansion of the number of people who identify themselves with a given movement, creation of basic communities, coordination, patience with the process of integration and development. ${ }^{95}$ How strong was Pope Francis's call for the unity of

.va/content/synod2018/en/fede-discernimento-vocazione/final-document-of-the-synod-of -bishops-on-young-people--faith-an.pdf (accessed: 30.09.2019).

${ }_{91}$ "Above all the acknowledgment in theory of the active and responsible presence of woman in the Church must be realized in practice." ChL, n. 51.

${ }_{92}$ ChL, n. 51.

93 "Papież powołał dwie kobiety na doradczynie w najważniejszej dykasterii Kurii Rzymskiej." See: http://www.deon.pl/kosciol/serwis-papieski/papiez-powolal-dwie-kobiety -na-doradczynie-w-najwazniejszej-dykasterii-kurii-rzymskiej,477629 (accessed: 21.09.2019).

94 "Claudia Ciocca pierwszą w historii kobietą na czele dykasterii w Watykanie."

See: http://www.misyjne.pl/claudia-ciocca-pierwsza-kobieta-szefem-dykasterii-w-watyka nie/ (accessed: 21.09.2019).

${ }^{95}$ Cf. C.B. Clark: Budowanie wspólnot chrześcijańskich. Strategia odnowy Kościoła. Trans. T. KosıEK. Wrocław-Kraków 1994, pp. 173-182. 
these aspects: "We need to pay attention to the global so as to avoid narrowness and banality. Yet we also need to look to the local, which keeps our feet on the ground. [...] The whole is greater than the part, but it is also greater than the sum of its parts. There is no need, then, to be overly obsessed with limited and particular questions. We constantly have to broaden our horizons and see the greater good which will benefit us all." 96

\section{Summary}

a) In the life and execution of the tasks of the Church one cannot understand the lay only as objects of pastoral activity, but also as its important subject: "Every one of us possessing charisms and ministries, diverse yet complementary, works in the very same vineyard of the Lord." 97

b) In the Church, it is important to correctly understand synodality which expresses the passage into a common path and which is organically connected with the understanding of the Church as communion. The equal dignity of the baptised and the common responsibility of the faithful for the life and mission of the Church requires an effective cooperation of all her members. This does not mean democratisation, which would limit the execution of bishops' ministry, since they are the shepherds and they make final decisions in the discernment process.

c) Synodality and discernment require the faithful to lead a spiritual life since their purpose is to protect the legacy passed down by Jesus. Only by living in the Holy Spirit can one recognise signs of the times, the state of the Church, and above all the will of God for a local and universal Church. Otherwise, it would be merely a matter of earthly determination of needs and solutions. This would not serve the execution of the Church's saving mission. It is worth remembering that many times in history institutions followed charismatic discernment.

d) For the Catholic Church, a broader participation of the lay in the discernment process remains a challenge. While the Pope and the bishops should undoubtedly make final decisions, the freer participation of the lay in discussions, discernment, and suggesting solutions should nevertheless be sanctioned canonically.

\footnotetext{
${ }^{96}$ Francis: Apostolic Exhortation Evangelii gaudium [24.11.2013], n. 234-235.

${ }^{97}$ ChL, n. 55.
} 
e) The Synod also has its boundaries, regardless of the opinion of the majority. These boundaries are the preservation of purity of doctrine, unity of the Church and the real common good of the ecclesiastical community and individual believers.

f) For structural and administrative actions are not enough for proper discernment (e.g. bishops' decrees). The Church needs a current, new look and something more than already existing solutions.

\section{Bibliography}

Catechism of Catholic Church [11.10.1992]. Available at: http://www.vatican.va /archive/ENG0015/_INDEX.HTM (accessed: 10.12.2019).

Clark S. B.: Budowanie wspólnot chrześcijańskich. Strategia odnowy Kościoła. Trans. T. Kosiek. Wrocław-Kraków 1994.

Claudia Ciocca pierwsza $w$ historii kobieta na czele dykasterii $w$ Watykanie. Available at: http://www.misyjne.pl/claudia-ciocca-pierwsza-kobieta-szefem -dykasterii-w-watykanie/ (accessed: 21.09.2019).

Code of Canon Law [15.01.1983]. Available at: http://www.vatican.va/archive /cod-iuris-canonici/cic_index_en.html (accessed: 15.09.2019).

Congregation for the Doctrine of the Faith: Letter to the Bishops of the Catholic Church on some aspects of the Church understood as communion [28.05.1992]. Available at: http://www.vatican.va/roman_curia/congrega tions/cfaith/documents/rc_con_cfaith_doc_28051992_communionis-notio_ en.html (accessed: 21.09.2019).

CONGREgation For the Doctrine of the Faith: Letter Iuvenescit Ecclesia to the Bishops of the Catholic Church Regarding the Relationship Between Hierarchical and Charismatic Gifts in the Life and the Mission of the Church [15.05.2016]. Available at: http://www.vatican.va/roman_curia/congregations /cfaith/documents/rc_con_cfaith_doc_20160516_iuvenescit-ecclesia_en .html. (accessed: 21.09.2019).

CoRdes P. J.: "Rola ruchów i stowarzyszeń katolickich w Kościele i w nowoczesnym społeczeństwie." In: Chrystus-Człowiek-Społeczności. Wiosna ruchów. Materiały z I Kongresu Ruchów Katolickich. Eds. K. BolewsKa, B. JANIKOWsKA, Warszawa 1994, pp. 40—51.

"Evangelizzazione e ministeri. Documento pastorale dell'Episcopato italiano." In: Notiziario della Conferenza Episcopale Italiana a cura della Segreteria Generale. Roma 1977, pp. 109-152.

FrancIS: Apostolic Exhortation Evangelii gaudium [24.11.2013]. Available at: http://www.vatican.va/content/francesco/en/apost_exhortations/documents /papa-francesco_esortazione-ap_20131124_evangelii-gaudium.html (accessed: 21.09.2019). 
Gdzie jest Bóg, tam jest przyszłość. XLIII Synod Diecezji Płockiej. Prawo partykularne i program odnowy pastoralnej Kościoła Płockiego. Ed. H. SeweryniaK. Płock 2015.

Giovanni Paulo II: “Crescita comune nell'unità e nella collaborazione reciproca.” In: Insegnamenti di Giovanni Paolo II, X, 1, 1987, 478. Vaticano 1988.

Giovanni Paulo II: Discorso di Giovanni Paolo II a conclusione della VI Assemblea Generale del Sinodo dei Vescovi. Available at: http://www.vatican.va/content /john-paul-ii/it/speeches/1983/october/documents/hf_jp-ii_spe_19831029_ sinodo-vescovi.html (accessed: 16.09.2019).

I (XIV) Synod Archidiecezji Warmińskiej (2006-2012). Eds. W. NowaK, P. RaBCZYŃsKi, L. ŚwiTo. Olsztyn 2012.

IV Synod Archidiecezji Warszawskiej. Warszawa 2003.

International Theological Commission: La sinodalità nella vita e nella missione della Chiesa. Available at: http://www.vatican.va/roman_curia/congre gations/cfaith/cti_documents/rc_cti_20180302_sinodalita_it.html (accessed: 21.09.2019).

John Paul II: Apostolic Exhortation Christifideles laici [30.12.1988]. Available at: http://www.vatican.va/content/john-paul-ii/en/apost_exhortations/docu ments/hf_jp-ii_exh_30121988_christifideles-laici.html (accessed: 20.09.2019).

John Paul II: Apostolic Letter Novo millennio ineunte [6.01.2001]. Available at: http://www.vatican.va/content/john-paul-ii/en/apost_letters/2001/docu ments/hf_jp-ii_apl_20010106_novo-millennio-ineunte.html (accessed: 20. 09.2019).

Kim jest świecki? Available at: http://www.papiez.wiara.pl/doc/1272559.Kim-jest -swiecki (accessed: 15.09.2019).

La Chiesa italiana e le prospettive del Paese Documento del Consiglio Permanente. Available at: http://www.chiesacattolica.it/wpcontent/uploads/sites /31/2017/02/La_Chiesa_italiana_e_le_prospettive_del_Paese.pdf (accessed: 14.09.2019).

Liverani P. G.: Dobre życie Ewangelia. W poszukiwaniu zaginionego powołania. Trans. K. WoźNiaK. Kraków 2012.

Papież powołat dwie kobiety na doradczynie $w$ najważniejszej dykasterii Kurii Rzymskiej. Available at: http://www.deon.pl/kosciol/serwis-papieski/papiez -powolal-dwie-kobiety-na-doradczynie-w-najwazniejszej-dykasterii-kurii -rzymskiej,477629 (accessed: 21.09.2019).

PAwe€ VI: Apostolic Letter Apostolica sollicitudo [15.09.1965]. Available at: http:// www.vatican.va/content/paul-vi/en/motu_proprio/documents/hf_p-vi_ motu-proprio_19650915_apostolica-sollicitudo.html (accessed: 20.09.2019).

Pierwszy Synod Diecezji Kaliskiej (2007-2009). Prawo diecezjalne Kościoła Kaliskiego. Eds. J. BąK, N. Buerger. Kalisz 2009.

Pierwszy Synod Diecezji Opolskiej (2002-2005). Statuty i aneksy. Parafia u progu nowego tysiaclecia. Eds. H. Sobeczкo et al. Opole 2005.

RYєко S.: Misja Ruchów i Stowarzyszeń na nowe tysiąclecie. Available at: http://www .orrk.pl/ruchy-katolickie-w-kociele-i-spoeczestwie/134-misja-ruchow-i-sto warzysze-na-nowe-tysiclecie (accessed: 18.09.2019). 
Ryś G.: "Rozmawiając z Franciszkiem o Dokumencie z Aparecidy.” In: Aparecida. V Ogólna Konferencja Episkopatów Ameryki Łacińskiej i Karaibów. Dokument końcowy. Trans. K. Zabawa, K. Łukaszczyk. Gubin 2014, pp. 7-9.

Sacred Congregation for Religious and for Secular Institutes, Sacred ConGREGATION FOR BISHOPS: Mutuae relationes. Directives for the mutual relations between bishops and religious in the Church [14.09.1978]. Available at: http:// www.vatican.va/roman_curia/congregations/ccscrlife/documents/rc_con_ ccscrlife_doc_14051978_mutuae-relationes_en.html (accessed: 20.09.2019).

Synod Archidiecezji Poznańskiej 2004-2008. Tom I. Dokumenty. Eds. Z. FortuNIAK et al. Poznań 2008.

Synod Młodych Diecezji Warszawsko-Praskiej. Available at: http://www.florian ska3.pl/synod (accessed: 16.09.2019).

Tymosz S.: Recepcja nauczania Jana Pawła II w uchwałach Drugiego Polskiego Synodu Plenarnego. Lublin 2010.

Vatican Council II: Decree concerning the Pastoral Office of Bishops in the Church “Christus Dominus" [28.10.1965]. Available at:http://www.docu mentacatholicaomnia.eu/03d/1965-10-28,_Concilium_Vaticanum_II,_ Decretum_\%27Christus_Dominus\%27,_EN.pdf. Accessed: 23 IX 2019.

Vatican Council II: Decree on the Apostolate of the Laity Apostolicam actuositatem (18.11.1965). Available at: http://www.vatican.va/archive/hist_coun cils/ii_vatican_council/documents/vat-ii_decree_19651118_apostolicam -actuositatem_en.html (accessed: 20.09.2019).

Vatican Council II: Decree on the mission activity of the Church Ad gentes [18.11. 1965). Available at: http://www.vatican.va/archive/hist_councils/ii_ vatican_council/documents/vat-ii_decree_19651207_ad-gentes_en.html (accessed: 21.09.2019).

Vatican Council II: Dogmatic Constitution on Divine Revelation Dei Verbum [18.11. 1965]. Available at: http://www.vatican.va/archive/hist_councils/ii_ vatican_council/documents/vat-ii_const_19651118_dei-verbum_en.html (accessed: 20.09.2019).

Vatican Council II: Dogmatic Constitution on the Church Lumen gentium [21.11. 1964]. Available at: https://www.vatican.va/archive/hist_councils/ii_ vatican_council/documents/vat-ii_const_19641121_lumen-gentium_en.html (accessed: 19.09.2019).

"Watykan przestrzega biskupów niemieckich przed 'drogą synodalną.." http:// www.gosc.pl/doc/5850492.Watykan-przestrzega-biskupow-niemieckich -przed-droga-synodalna (accessed: 13.09.2019).

Weron E.: Powołanie i posłannictwo ludzi świeckich $w$ świetle dokumentów kościelnych. Poznań 1989.

Weron E.: Ruchy odnowy we wspótczesnym Kościele. Poznań 1993.

XV General Assembly of the Synod of Bishops: "Final Document of the Synod of Bishops on Young People, Faith and Vocational Discernment." Available at: http://www.synod.va/content/synod2018/en/fede-discernimento-vocazi one/final-document-of-the-synod-of-bishops-on-young-people--faith-an.pdf (accessed: 30.09.2019). 
PRZEMYSŁAW SAWA

\section{Synodalité, discernement, mouvements ecclésiaux}

Résumé

L'une des catégories fondamentales décrivant la nature de l'Église est la communion, qui a une dimension spirituelle, structurelle et juridique. En vertu du saint baptême, tous les fidèles doivent donc assumer une responsabilité commune et prendre vraiment soin de la vie et des secteurs particuliers de l'activité de l'Église. Cela inclut aussi le phénomène du discernement dans l'Église. Les synodes, ainsi qu'une synodalité au sens large, sont un espace spécial où s'exprime le caractère communautaire de l'Église.

La synodalité et le discernement communautaire, cependant, ne peuvent pas être compris de la même manière que le parlement et la prise de décision à la majorité. Il s'agit de discerner les besoins contemporains et de se découvrir en tant qu'Église dans le monde, tout en gardant la vérité révélée.

Les mouvements ecclésiaux qui forment des catholiques s'identifiant de plus en plus à la mission des baptisés sont essentiels pour reconnaître les chemins de l'Église. Le défi qui reste à affronter, c'est d'approfondir leur importance et de déterminer l'étendue de leur impact sur le processus de discernement dans l'Église, tant au niveau universel que local.

Mots clés: synodalité, discernement, implication laïque, structure de l’Église, mouvements et communautés ecclésiaux

PrZemysŁaW SAWA

\section{Sinodalità, discernimento, movimenti ecclesiali}

\section{Sommario}

Una delle categorie fondamentali che descrivono la natura della Chiesa è la comunione nella sua dimensione spirituale, strutturale e giuridica. In virtù del santo battesimo, tutti i fedeli dovrebbero quindi assumersi la responsabilità comune e curare realmente la vita e i singoli settori dell'attività della Chiesa. Ciò include anche il fenomeno del discernimento nella Chiesa. I Sinodi, così come la sinodalità ampiamente intesa, sono uno spazio speciale dove si esprime il carattere comunitario della Chiesa.

La sinodalità e il discernimento comunitario, tuttavia, non possono essere intesi allo stesso modo che il parlamento e il processo decisionale a maggioranza. Si tratta di discernere i bisogni contemporanei e il modo in cui la Chiesa si trova nel mondo, custodendo la verità rivelata.

I movimenti ecclesiali formano i cattolici che si identificano sempre di più con la missione dei battezzati sono quindi essenziali per riconoscere le strade per la Chiesa. La sfida da affrontare resta quella di approfondire la loro importanza e di determinare la portata della loro influenza sul processo di discernimento nella Chiesa, sia a livello universale che locale.

Parole chiave: sinodalità, discernimento, coinvolgimento dei laici, struttura ecclesiale, movimenti ecclesiali e comunità 